\title{
EVALUASI PASCA HUNI BANGUNAN BRAGA CITY WALK BANDUNG
}

\author{
Astrid Austranti Yuwono \\ (Email: austranti@yahoo.com) \\ Program Studi Desain Interior \\ Fakultas Seni Rupa dan Desain \\ Universitas Kristen Maranatha \\ Jl. Prof. Drg. Surya Sumantri No 65, Bandung, Indonesia
}

\begin{abstract}
ABSTRAK
Braga City Walk terletak di Jalan Braga yang merupakan kawasan konservasi di kota Bandung. Wilayah Braga pada masa kejayaannya menjadi daya tarik utama kota Bandung yang dikenal sebagai "Parijs van Java". Beberapa tahun lalu Braga dalam kondisi terlantar ditunjukkan oleh bangunanbangunan tua kurang terawat serta kegiatan ekonomi yang kurang bergairah. Braga City Walk dirancang sebagai pusat gaya hidup bertema yang lebih menonjolkan kegiatan hiburan dan rekreasi dari sekedar berbelanja. Kondisi Braga City Walk saat ini masih banyak jumlah ruang sewa yang kosong, perubahan yang telah dilakukan selama perkembangannya menunjukkan upaya mengubah kondisi tersebut.Penelitian ini dilakukan untuk membuat evaluasi pasca huni(indicative level) performa bangunan Braga City Walk, Bandung. Metode penelitian yang digunakan adalah denganstudi pustaka, pengumpulan data melalui data gambar bangunan eksisting serta pengamatan walk-through setiap jalur yang dilewati pengunjung yang menghasilkan data fisik meliputi lokasi, tata letak lingkungan, tata ruang, sistem sirkulasi, serta material; pengamatan latar belakang lingkungan yang menghasilkan data non-fisikmencakup perkembangan lingkungan kompleks, pengelolaan kompleks, serta perilaku pengguna. Dalam kasus Braga City Walk, faktor yang ternyata mempengaruhi nilai bangunan ini adalah penentuan fungsi (faktor fisik), dalam hal ini pertimbangan karakter ruang sewa, yang kemudian mempengaruhi desain tata ruang dan membentuk pola sirkulasi dalam bangunan. Karena masalah berakar pada karakter ruang sewa, solusinya adalah untuk menciptakan sebuah konsep baru dengan memperhatikan potensi lingkungan sekitarnya (faktor non-fisik).Selain itu, perbaikan fisik yang mutlak harus dilakukan untuk membentuk kembali pola sirkulasi sirkuit yang ideal supaya pengunjung diarahkan dapat mengelilingi ruang-ruang sewa tanpa menemui alur sirkulasi yang buntu.
\end{abstract}

Kata Kunci: braga city wal; evaluasi pasca huni; perencanaan; ruang; sirkulasi

\begin{abstract}
Braga City Walk is located at Jalan Braga which is a conservation area in Bandung city. Braga region used to be the main attraction of Bandung which was known as "Parijs van Java". Few years ago Braga was in derelict condition that is shown by the old buildings that are mostly less well maintained as well as the economic activities that are less passionate. Braga City Walk was designed as a themed lifestyle center, which further highlight the entertainment activities and recreational/leisure activities than just shopping. Braga City Walk conditions now still have a large amount of rental space that is empty, the changes that have been made during its development showthat they tried to change that situation. This research was conductedtomake apost-occupancy evaluation at indicativelevel. The method usedare literatures review, collectingdatafrom building's drawings, and with awalk-through observationof eachpath of the interior which will generatethe physical factorsincludethe location, the layout ofthe environment, spatial, circulatory system, as well asmaterial. Theobservation ofenvironmental backgroundwill producenonphysical factors includedevelopment ofcomplexenvironments, management ofthe complex, as well asuser behavior.In the case of Braga City Walk, factors affecting the value of this building is the determination of
\end{abstract}


the function (physical factor), in this case the consideration of the character of rental space, which then affects the spatial design and immediately establish the circulation patterns within the building. Since the judgment rooted in the character of the room rent, the solution is to create a new concept bypay attention to the potential of the surrounding environment (non-physical factor). Furthermore, the physical improvement that absolutely must be done is to reshape the circulation pattern of the ideal circuit, where visitors directed convenient to go around the complex without encountering dead-end spaces.

Keywords: bragacity walk; circulation; planning; post-occupancy evaluation; space

\section{PENDAHULUAN}

Braga City Walk terletak di Jalan Braga yang merupakan kawasan konservasi di Kota Bandung. Kawasan Braga yang dahulu merupakan daya tarik utama Kota Bandung sebagai Parijs van Java beberapa tahun belakangan berada dalam kondisi yang terlantar. Kawasan ini hanya menyisakan bangunan lama yang sebagian besar kurang terawat serta kegiatan ekonomi yang kurang bergairah. Meskipun demikian, saat ini pemerintah Kota Bandung sudah mulai mengupayakan berbagai hal untuk membangkitkan kembali daya tarik Braga.

Pada masa kejayaannya, kawasan Braga menjadi tempat yang disenangi orang banyak untuk rekreasi jalan kaki di pusat kota. Sebagian pengunjung acara jaarbeurs dan pacuan kuda, menyempatkan diri untuk jalan-jalan di kawasan Braga. Oleh karena itu, tepat apabila Pemerintah Kota Bandung memiliki program menertibkan kawasan Braga(Dr. A. Sobana Hardjasaputra, seorang peneliti sejarah, dimuat dalam Harian PR , 28 Maret 2007).

Mulai dibangun pada tahun 2004, proyek Braga City Walk menjadi kontroversi karena proyek ini dianggap tidak cukup memberikan dampak positif pada program konservasi bangunan di Jalan Braga. Sesuai pernyataan Ketua Bandung Heritage Society, Dr. Harastoeti Dibyo Hartono, Ir., MSA., sebuah pusat perbelanjaan, apartemen, supermarket, dan hotel tidak cukup untuk menjadi daya tarik bagi masyarakat untuk mengunjungi Jalan Braga, justru hanya akan menimbulkan kemacetan lalu lintas yang diakibatkan banyaknya jumlah kendaraan yang ingin memasuki kompleks tersebut.

Braga City Walk dirancang dalam sebuah pengembangan mixed use bertemakan lifestyle center, lebih menonjolkan kegiatan hiburan (entertainment) dan rekreasi (leisure) dibandingkan sekedar kegiatan berbelanja. 
Saat penelitian ini dilakukan kondisi Braga City Walkmasih memiliki banyak ruang sewa yang kosong, perubahan-perubahan yang telah dilakukan semasa perkembangannya menjadi gambaran upaya untuk dapat mengubah keadaan tersebut.

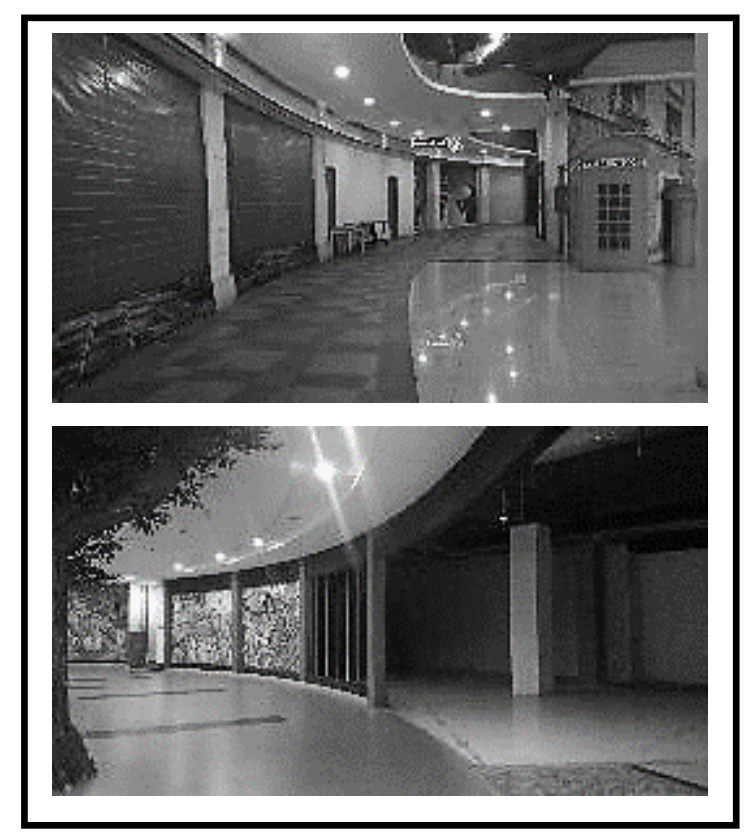

Gambar 1. Ruang-ruang sewa yang kosong Sumber: Dokumentasi pribadi, 2015

Evaluasi pasca huni menjadi salah satu cara untuk menentukan perubahan seperti apayang harus dilakukan. Melalui evaluasi pasca huni, akan didapatkan indikasi masalah yang harus dipecahkan dengan lebih cermat.

\section{METODE PENELITIAN}

Evaluasi pasca huni (POE $=$ Post-Occupancy Evaluation) memiliki beberapa tingkat yakni Indicative $P O E$, Investigate $P O E$, dan yang paling tinggi adalah Diagnostic POE (Preiser, 1988).Penelitian ini termasuk dalam indicative $P O E$ yaitu dilakukan untuk menemukan indikasi masalah utama dari sebuah bangunan yang sudah digunakan.

Metode pengumpulan data untuk tingkat evaluasi pasca huni dalam penelitian ini adalah melalui (1)studi pustaka; (2)data gambar denahbangunan sehingga dapat dianalisis perubahan-perubahan yang terjadi serta pemetaan ruang-ruang yang ada;(3)pengamatan walk-through dilakukan dengan pengamatan ruang demi ruang dalam bangunan dan mendokumentasikan hal-hal yang menarik perhatian untuk dianalisis.Data-data tersebut kemudian akan dibahas menjadi dua faktor yakni faktor fisik yang meliputi lokasi, tata 
lingkungan sekitar, tata ruang dalam, sistem sirkulasi, serta material. Faktor non-fisik akan meliputi riwayat perkembangan lingkungan kompleks, manajemen pengelolaan kompleks, perilaku pengguna.Beberapa studi literatur mengacu pada definisi, pengertian, dan analisis terkait faktor fisik dan non-fisik lifestyle center.

\section{Pusat Perbelanjaan}

Menurut Peraturan Menteri Perdagangan RI No. 70/M-DAG/PER/12/2013:

"Pusat Perbelanjaan adalah suatu area tertentu yang terdiri dari satu atau beberapa bangunan yang didirikan secara vertikal maupun horisontal, yang dijual atau disewakan kepada pelaku usaha atau dikelola sendiri untuk melakukan kegiatan perdagang-an barang."

Menurut International Council of Shopping Centers (ICSC, 2004) dalam Reikli (2012), berdasarkan desainnya, pusat perbelanjaan terbagi menjadi shopping mall, open-air centers, danhybrid centers. Dalam beberapa liputan di majalah desain, Braga City Walk mengusung tema lifestyle center dalam sebuah mixed use development. Lifestyle center termasuk dalam kategori open-air centers.

Menurut Reikli (2012) dari sudut pandang bisnis, sebuah pusat perbelanjaan bukan sekedar 'tempat' melainkan juga adalah sebuah 'produk' yang sedemikian rupa menggabungkan antara nilai lokasi, tenant mix, dan customer mix. Pernyataan tersebut menjadikan perancangan sebuah pusat perbelanjaan tidak semata pada fisik atau desain 'bagus' semata.Hubungan timbal balik antara faktor fisik dan non-fisik harus menjadi sinergi dalam menciptakan 'produk' yang diminati.

Terkait karakteristik fisiknya Kramer, et. Al (2008) dalam Reikli (2012) menyatakan beberapa karakteristik sebuah pusat perbelanjaan yang dirancang dengan baik diantaranya yaitu: memiliki tata ruang dan bangunan yang baik, mudah dicapai, memiliki cukup lahan parkir, tata ruang nyaman yang menimbulkan kesan dan ingatan menyenangkan. Memahami beberapa karakter fisik tersebut akan membawa pada ambiance yang membuat sekedar 'tempat' menjadi 'produk'.

\section{Konsep Mixed Use}


Menurut Levy dan Weitz (2008) dalam Reikli (2012), kawasan mixed use development terdiri dari beberapa bangunan yang multi fungsi. Berbagai fungsi dapat tumbuh bersebelahan, baik berupa perkantoran, pusat belanja, pemukiman, pusat budaya, dan lain-lain.

Mixed use secara umum merupakan sebuah blok yang memiliki ragam fungsi dalam bangunan yang berbeda-beda namun saling mendukung. Baik itu pemukiman atau kumpulan fungsi bisnis yang dilengkapi oleh pedestrian sebagai penghubung.

\section{Lifestyle Center}

Menurut International Council of Shopping Centers (ICSC, 2004) dalam Reikli (2012), Lifestyle Centers dibangun di tengah kawasan pemukiman yang memiliki produktivitas tinggi untuk memenuhi kebutuhan berbelanja dan gaya hidup penduduk di kawasan tersebut. Produk yang dijual adalah produk khusus yang berkualitas tinggi sehingga dari sudut harga pun lebih tinggi dibanding produk sejenis yang dijual di pasaran. Dengan mengacu pada konsep rekreasi, fasilitas yang disediakan juga mencakup restoran, hiburan, dan dengan suasana yang menarik.

Titik berat fungsi sebuah lifestyle center adalah pada fasilitas terkait rekreasi (leisure) dan hiburan (entertainment). Menurut Coleman (2006), fasilitas tersebut membangkitkan kenyamanan bagi pengunjung sehingga juga berpengaruh pada kecenderungan minat beli mereka. Lifestyle center memiliki target market yang spesifik seperti kawula muda profesional yang cenderung masuk dalam kategori menengah ke atas. Jenis toko harus dapat memenuhi kenginan dari karakter target market tersebut.

\section{Sirkulasi Dalam Pusat Perbelanjaan}

Sirkulasi publik adalah elemen yang menghubungkan dan mengorganisir berbagai bagian dalam sebuah pusat perbelanjaan karena sebagai salah satu hal penting dalam proses perancangan sebuah pusat perbelanjaan.

"The circulation space forms the planning structure and layout and, as such, will determine the building's success" (Coleman, 2006:329)

Coleman (2006) menyatakan ada tiga dasar pola sirkulasi pusat perbelanjaan yakni Linear, Circuit, dan Keyhole. 


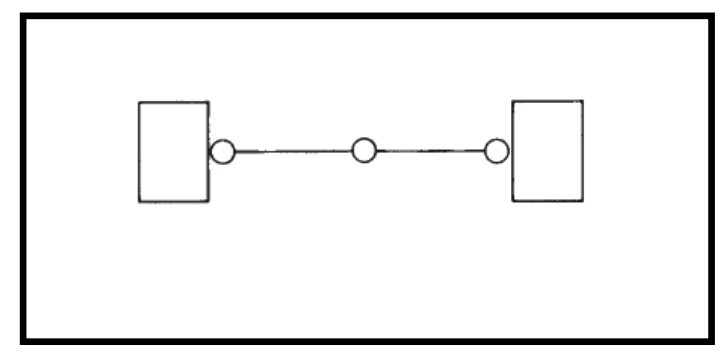

Gambar 2. Pola sirkulasi linear Sumber: Coleman (2006:341)

Pada pola sirkulasi linear, pengunjung akan cenderung mengalami kelelahan karena jarak yang sangat panjang. Penempatan fasilitas duduk dan desain yang tidak monoton menjadi tantangan pada jenis sirkulasi ini.

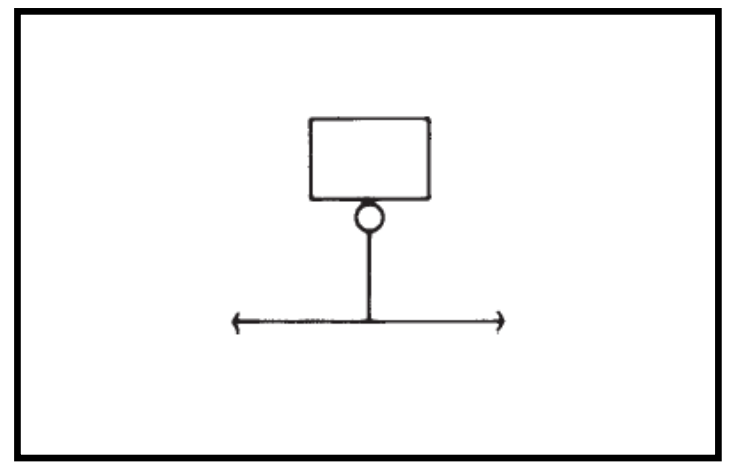

Gambar 3. Pola sirkulasi keyhole

Sumber: Coleman (2006:341)

Pada pola sirkulasi keyhole, posisi anchor tenant (penyewa ruang jual yang memiliki daya tarik pengunjung paling besar) menjadi magnet utama. Konsekuensi pola sirkulasi seperti ini adalah permainan 'kutub magnet' antara akses pengunjung dan anchor tenant yang membuat seluruh ruang sewa di jalur sirkulasi menuju anchor tenant dilewati oleh pengunjung.

Mengingat keterbatasan luas tanah Braga City Walk maka pola sirkulasi yang disarankan adalah pola sirkuit karena memungkinkan setiap pengunjung dapat melewati semua toko dan kembali ke titik awal tanpa harus mengulang melewati jalur yang sama. Pola ini juga memungkinkan penataan agar semua toko dapat terlihat oleh pengunjung. 


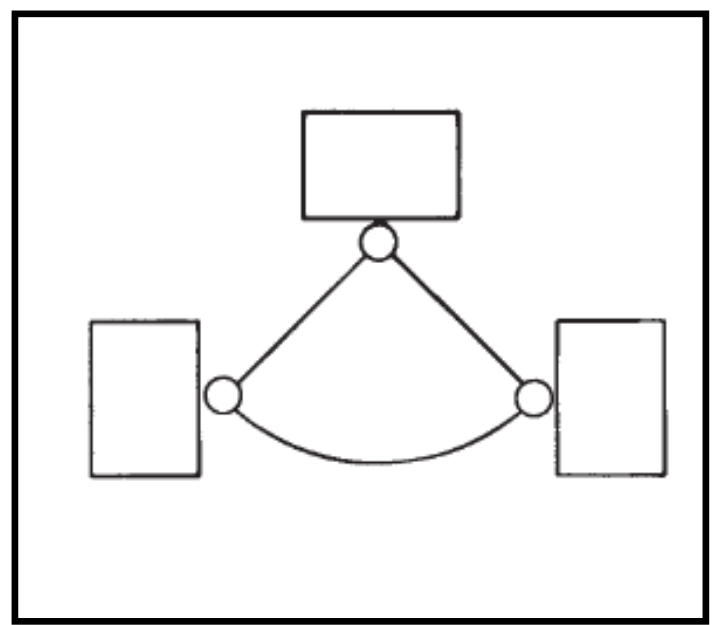

Gambar 4. Pola sirkulasi sirkuit

Sumber: Coleman (2006:341)

\section{Karakteristik Perilaku}

\section{Belanja Konsumen}

Menurut Bromley (1993), perilaku berbelanja terkait dengan tujuan aktivitas belanja dilakukan.

Tabel 1. Perbandingan tujuan berbelanja

\begin{tabular}{|l|l|}
\hline TUJUAN FUNGSIONAL & TUJUAN HIBURAN \\
\hline Dapat diduga & $\begin{array}{l}\text { Memiliki varian nilai, } \\
\text { spesifik }\end{array}$ \\
\hline $\begin{array}{l}\text { Berdasarkan kebutuhan } \\
\text { (needs) }\end{array}$ & $\begin{array}{l}\text { Menciptakan keinginan } \\
\text { (wants) }\end{array}$ \\
\hline $\begin{array}{l}\text { Memiliki target yang } \\
\text { jelas }\end{array}$ & $\begin{array}{l}\text { Browsing dan } \\
\text { Opportunistic }\end{array}$ \\
\hline $\begin{array}{l}\text { Memperhitungkan } \\
\text { efisiensi waktu }\end{array}$ & $\begin{array}{l}\text { Tidak } \\
\text { memperhitungkan } \\
\text { waktu }\end{array}$ \\
\hline
\end{tabular}

Sumber: Bromley (1993:212)

Gambaran perilaku konsumen tersebut dapat menjadi tolok ukur yang mempengaruhi perencanaan tata ruang dan sirkulasi, sehingga kesimpulan kriteria tata ruang dan sirkulasi berdasarkan perilaku konsumen adalah:

- Memiliki varian jenis barang yang dijual sehingga menaikkan minat pengunjung karena memiliki banyak pilihan dalam satu tempat

- Memiliki luasan yang cukup besar sehingga mampu menampung varian fasilitas dan aktivitas bagi pengunjung

- Memiliki suasana yang menarik untuk mendongkrak keinginan pengunjung untuk melakukan transaksi 
- Memiliki alur sirkulasi yang seolah-olah dapat membuat pengunjung lupa waktu, dilengkapi dengan fasilitas duduk dan desain suasana jalur sirkulasi.

\section{Data Fisik Obyek}

Nama $\quad$ : Braga City Walk

Lokasi $\quad$ : J. Braga No. 99-101

Bandung 40111,

Jawa Barat

Pembangunan :Tahun 2004

Pengembang : PT. Bangun Mitra Mandiri

Grup Bisnis : : Agung Podomoro Group

Luas Tanah : $: 8553 \mathrm{~m}^{2}$

Luas Bangunan : $44266 \mathrm{~m}^{2}$

Konsep : :Mixed use / Lifestyle Center

\section{Deskripsi Obyek}

Braga City Walk yang berada di jantung Kota Bandung ini mengusung konsep mix-used development building dengan menggabungkan area Shopping Arcade, Apartment, dan Aston Hotel \& Residence. Shopping Arcade berkonsep semi open air space dengan nuansa pedestrian walk sehingga dapat melanjutkan konsep belanja di Jalan Braga tempo dulu. Letaknya sangat strategis di pusat kota sehingga memiliki potensi sebagai meeting point. Memiliki total area pusat pembelanjaan seluas $15.063 \mathrm{~m}^{2}$, yang dibagi menjadi 3 (tiga) lantai area Shopping Arcade, dilengkapi dengan 4 (empat) lantai area parkir yang dapat memuat 505 unit mobil. 
Serat Rupa Journal of Design, September 2016, Vol.1, No.2: 222-246

Astrid Austranti - Evaluasi Pasca Huni Bangunan Braga City Walk Bandung

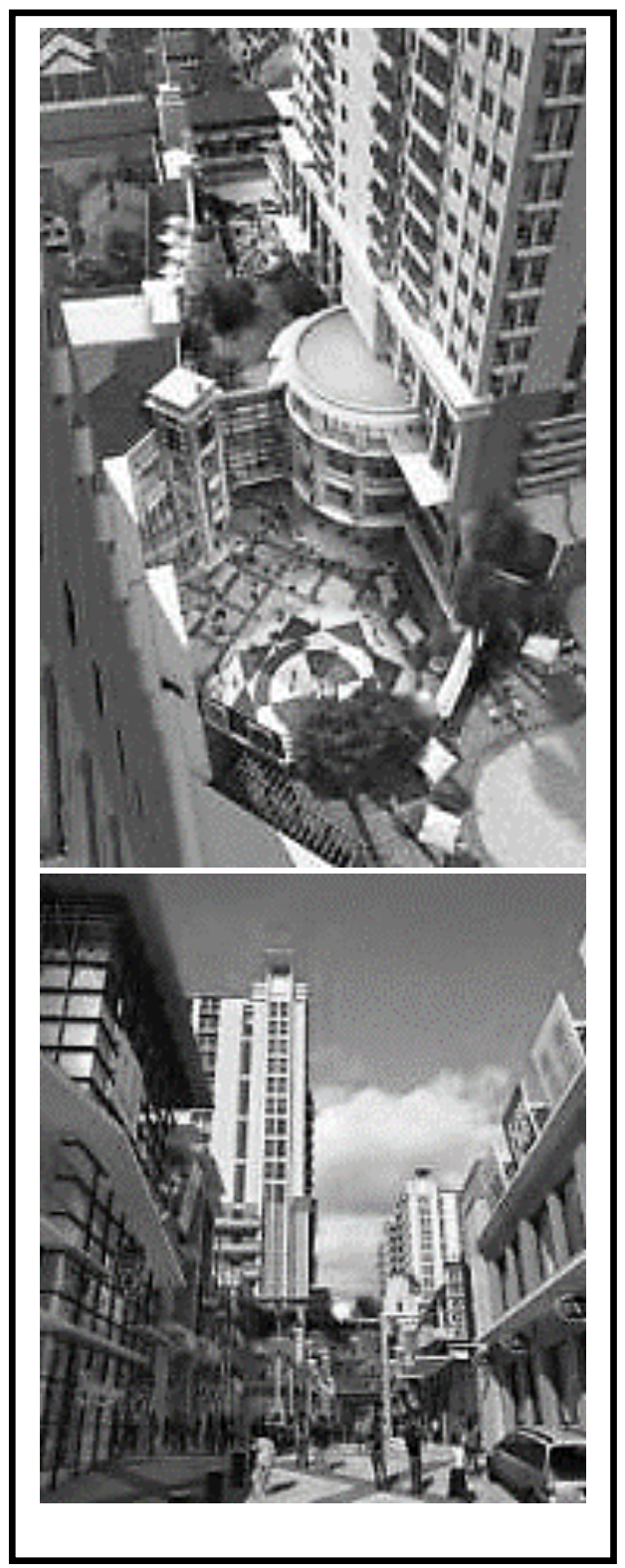

Gambar 5. Gagasan Awal Desain Braga City Walk

Sumber: Brosur Braga City Walk, 2005

Perubahan Pada Bangunan

Berikut di bawah ini adalah denah awal ketika Braga City Walk dibangun dan denah perubahan: 


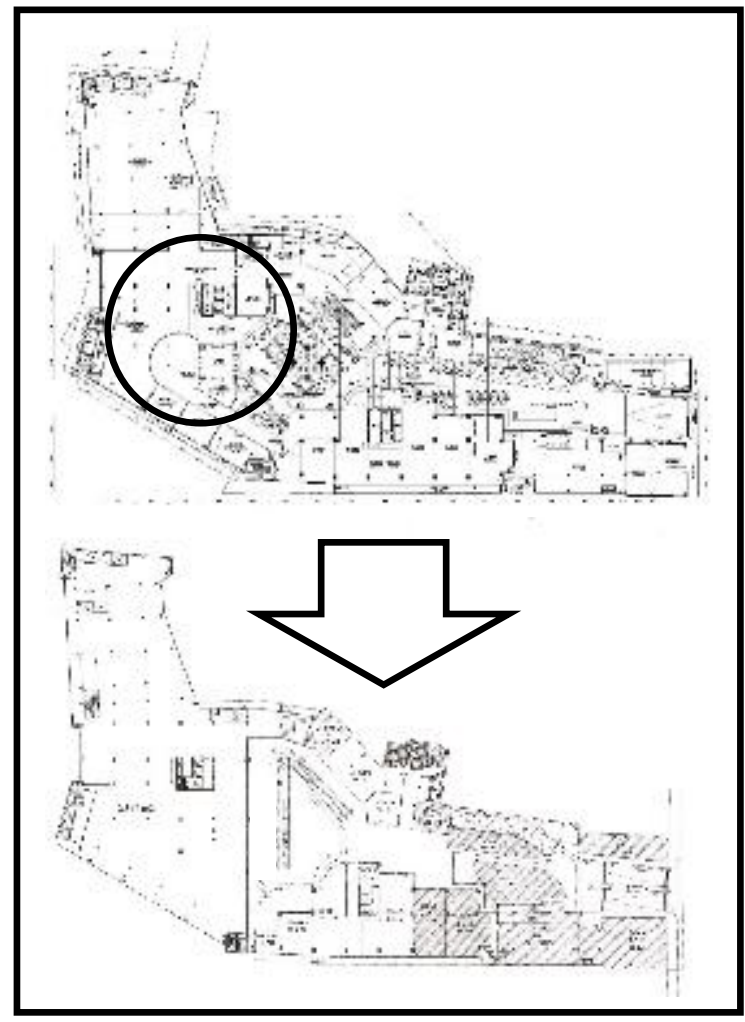

Gambar 6. Denah awal dan denah perubahan Lantai dasar-Braga City Walk

Sumber: PT. Bangun Mitra Mandiri, 2005-2015

Pada lantai dasar Braga City Walk, perubahan fisik terjadi di area void karena sempat ada penambahan travelator. Suasana void diubah dengan desain yang dianggap lebih menarik bagi pengunjung.

Beberapa ruang sewa diubah menjadi satu ruang sewa besar untuk anchor tenant. Saat itu sebuah hypermarket dianggap mampu menarik pengunjung. 


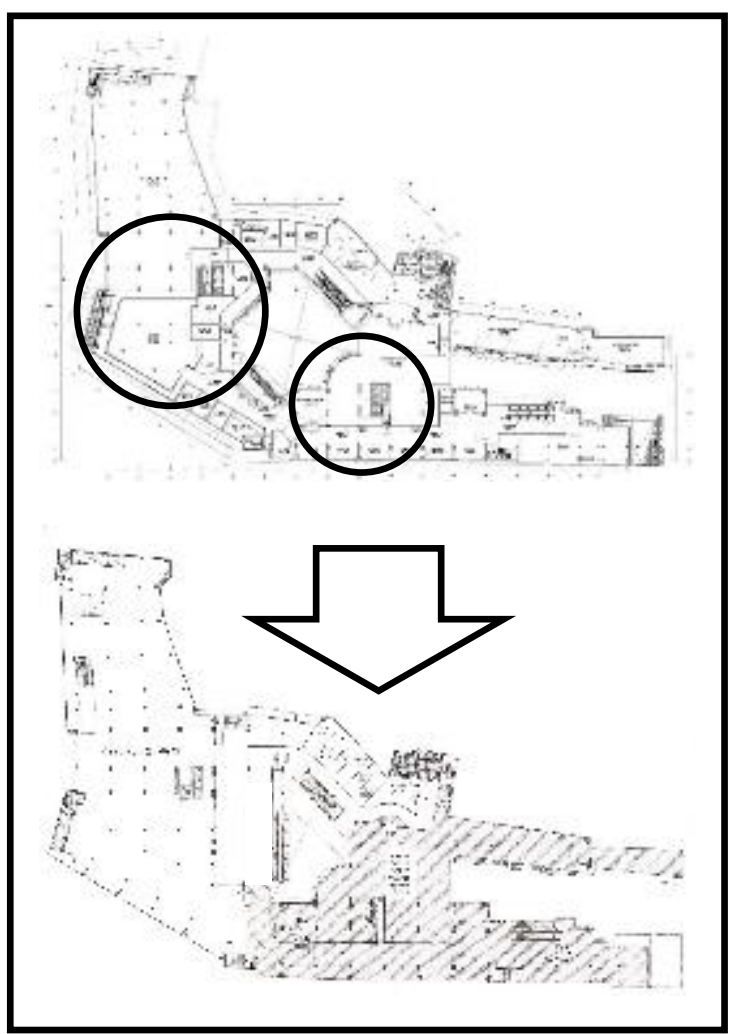

Gambar 7. Denah awal dan denah perubahan Lantai satu-Braga City Walk

Sumber: PT. Bangun Mitra Mandiri, 2005-2015

Denah lantai dua otomatis terkena imbas perubahan di lantai satu. Karena anchor tenant akan menggunakan dua lantai, maka pada lantai ini pun beberapa ruang sewa digabung untuk membentuk ruang sewa yang besar. Ruang-ruang sewa kecil lainnya yang ternyata juga tidak tersewa dibuat menjadi satu ruang sewa besar yang difungsikan sebagai toko furnitur.

Saat ini lokasi hypermarket telah menjadi hotel, sedangkan toko furnitur telah menjadi tempat karaoke. 


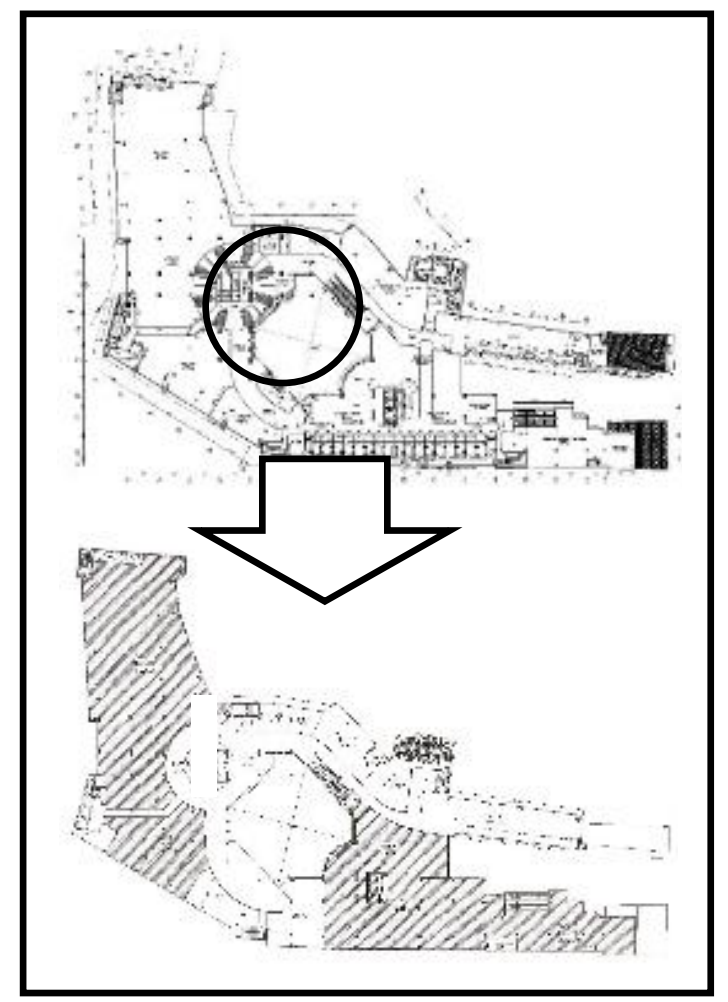

Gambar 8. Denah awal dan denah perubahan Lantai dua-Braga City Walk

Sumber: PT. Bangun Mitra Mandiri, 2005-2015

Pada lantai tiga, fungsi food court juga mengalami kondisi yang tidak sesuai harapan sehingga pada akhirnya juga dijual sebagai ruang sewa besar untuk pertemuan keagamaan.

Jika disimpulkan maka, perubahan pembagian fungsi adalah sebagai berikut:

Tabel 2. Perbandingan fungsi pada rencana awal

\begin{tabular}{|l|l|l|}
\hline \multicolumn{3}{|c|}{ RENCANA AWAL } \\
\hline \hline \multicolumn{1}{|c|}{ D } & \multicolumn{1}{|c|}{$\mathbf{1}$} & \multicolumn{1}{c|}{} \\
\hline Restoran & $\begin{array}{l}\text { Pusat } \\
\text { kebugaran }\end{array}$ & Cinema \\
\hline Café & Restoran & Timezone \\
\hline Meeting room & Café & Toko buku \\
\hline Retail & Salon & Restoran \\
\hline & Retail & Food court \\
\hline
\end{tabular}

Sumber: Dokumentasi pribadi, 2015

Tabel 3. Fungsi setelah mengalami dua kali perubahan

\begin{tabular}{|c|l|c|}
\hline \multicolumn{3}{|c|}{ KONDISI SAAT INI } \\
\hline \hline D & \multicolumn{1}{|c|}{$\mathbf{1}$} & \multicolumn{1}{c|}{} \\
\hline Restoran & $\begin{array}{l}\text { Pusat } \\
\text { kebugaran }\end{array}$ & Cinema \\
\hline
\end{tabular}




\begin{tabular}{|c|c|c|} 
Café & Restoran & Fimezone \\
\hline Meeting room & Café & Fokobuku \\
\hline $\begin{array}{c}\text { Retail } \\
\text { Pusat } \\
\text { kebugaran }\end{array}$ & Salon & Restoran \\
\hline $\begin{array}{c}\text { Fave Hotel } \\
\text { Lobby }\end{array}$ & Retail & Food court \\
\hline & $\begin{array}{c}\text { Fave Hotel } \\
\text { Functionroom }\end{array}$ & $\begin{array}{c}\text { Pusat } \\
\text { kebugaran }\end{array}$ \\
\hline & Karaoke & Tiberias \\
\hline
\end{tabular}

Sumber: Dokumentasi pribadi, 2015

Tingkat okupansi dapat diketahui melalui perbandingan jumlah luasan ruang sewa dalam status tersewa dengan luasan ruang sewa yang masih kosong. Gambaran tingkat okupansi ruang sewa di Braga City Walk adalah sebagai berikut:

Tabel 4. Prosentase tingkat okupansi ruang sewa
\begin{tabular}{|l||r|r|r|r|}
\hline & \multicolumn{4}{c|}{ TINGKAT OKUPANSI RUANG SEWA } \\
\hline \hline LANTAI & $\mathbf{D}$ & $\mathbf{1}$ & $\mathbf{2}$ & TOTAL \\
\hline $\begin{array}{l}\text { +LUAS } \\
\left(\mathbf{m}^{\mathbf{2}}\right)\end{array}$ & 1856 & 2380 & 3877 & $\mathbf{1 4 6 1 4}$ \\
\hline$\%$ & $36.89 \%$ & $44.11 \%$ & $89.16 \%$ & $\mathbf{5 5 . 5 1 \%}$ \\
\hline
\end{tabular}

Sumber: Dokumentasi pribadi, 2015

Beberapa perubahan fisik telah dilakukan, teramati sudah 2 (dua) kali mengalami renovasi yang cukup besar. Perubahan dilakukan untuk meningkatkan nilai ekonomi dengan meninjau ulang penyewa ruang 'tenant' seraya menyesuaikan dengan perubahan fungsi. Berikut adalah beberapa perubahan kasat mata terkait tata ruang dan sirkulasi:

Tabel 5. Perubahan fisik

\begin{tabular}{|c|l|l|}
\hline \multicolumn{3}{|c|}{ Tabel 5. Perubahan fisik } \\
\hline A & $\begin{array}{l}\text { Lantai } \\
\text { Dasar }\end{array}$ & $\begin{array}{l}\text { Perubahan peruntukan ruang } \\
\text { sewa dari meeting room menjadi } \\
\text { hotel }\end{array}$ \\
\hline B & $\begin{array}{l}\text { Lantai } \\
\text { Lasar, } \\
\text { \&antai 1 }\end{array}$ & Menghilangkan eskalator \\
\hline C & Lantai 1 & $\begin{array}{l}\text { Perubahan area wellness center } \\
\text { dan salon menjadi hotel }\end{array}$ \\
\hline D & Lantai 1 & $\begin{array}{l}\text { Relokasi fungsi wellness center ke } \\
\text { bagian depan kompleks }\end{array}$ \\
\hline E & Lantai 1 & $\begin{array}{l}\text { Perubahan bentuk void yang } \\
\text { dipengaruhi oleh perubahan } \\
\text { fungsi sebelumnya (Carrefour) }\end{array}$ \\
\hline & & $\begin{array}{l}\text { Perubahan peruntukan ruang } \\
\text { sewa dari koridor retail menjadi } \\
\text { rentable area }\end{array}$ \\
F & Lantai 1 & $\begin{array}{l}\text { Perubahan peruntukan ruang } \\
\text { sewa dari food court menjadi } \\
\text { rentable area }\end{array}$ \\
\hline & \multicolumn{2}{|c|}{ Sumber: $\begin{array}{l}\text { Dokumentasi pribadi, 2015 } \\
\text { G }\end{array}$} \\
\hline
\end{tabular}


Data perubahan di atas dapat diamati posisinya dalam skema per lantai berikut:

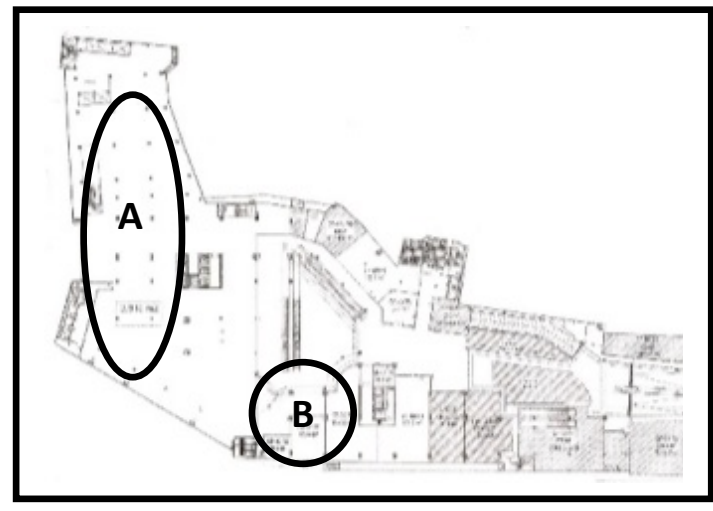

Gambar 9. Skema perubahan fisik Lantai dasar - Braga City Walk Sumber: Dokumentasi pribadi, 2015

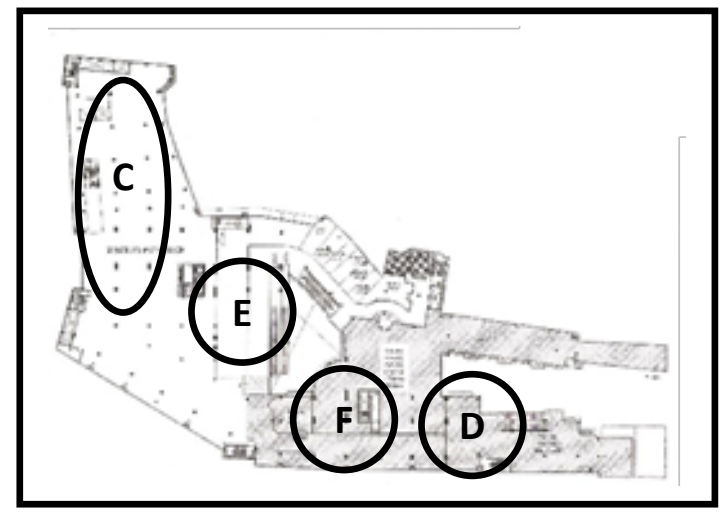

Gambar 10. Skema Perubahan Fisik Lantai Satu - Braga City Walk Sumber: dokumentasi pribadi, 2015

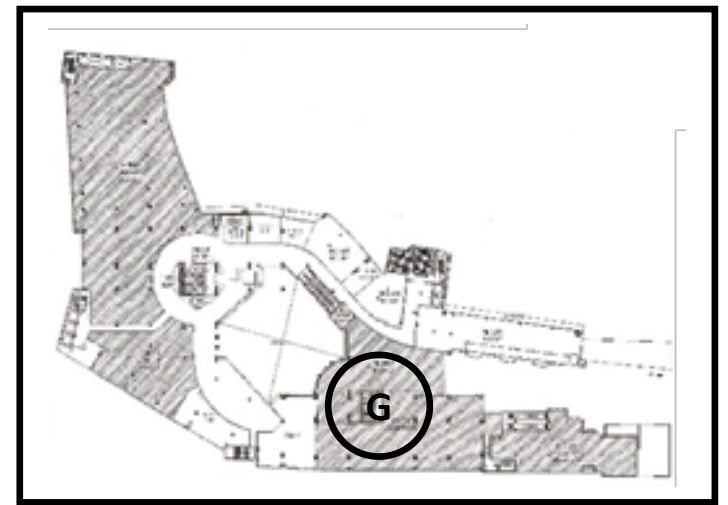

Gambar 11. Skema Perubahan Fisik Lantai Dua - Braga City Walk

Sumber: dokumentasi pribadi, 2015 


\section{PEMBAHASAN}

Faktor Non-Fisik

\section{a. Riwayat Perkembangan Lingkungan}

\section{Sekitar dan Citra Kawasan}

Sekitar abad ke-18 (Kunto, 1984), Jalan Braga menjadi ramai karena banyak usahawan terutama berkebangsaan Belanda mendirikan toko-toko, bar dan tempat hiburan di kawasan itu. Societeit Concordia yang digunakan untuk pertemuan para kalangan tuan-tuan hartawan, gedung perkantoran dan lain-lain di beberapa blok di sekitar jalan ini juga meningkatkan kemasyhuran jalan ini. Namun, pusat aktivitas sosial dan ekonomi di Kota Bandung ini dirasa tidak lengkap tanpa menghadirkan fasilitas hiburan sebagai tempat 'pelesiran' para bangsawan Belanda. Bar dan hiburan malam menjadikan kawasan ini kawasan remang-remang.

Riwayat perkembangan Braga tersebut membuat kawasan ini memiliki citra yang kurang baik.Upaya revitalisasi dilakukan dengan membersihkan kawasan ini dari fungsi hiburan malam.Citra kawasan Jalan Braga saat ini adalah sebagai koridor pertokoan yang berorientasi pada nilai historis.Upaya revitalisasi kerap dilakukan demi mengembalikan Braga sebagai ikon Kota Bandung.Namun citra kawasan yang sudah terbentuk sejak lama tidak mudah untuk diubah begitu saja.

Kelompok masyarakat yang terbentuk di sekitar lingkungan pun dipengaruhi dan mempengaruhi citra kawasan. Pemukiman di sekitar lokasi Braga City Walk merupakan pemukiman menengah ke bawah, yang tinggal di belakang deretan pertokoan, namun tidak sejalan dengan target konsumen Braga City Walk.

\section{b. Konsep dan Manajemen Pengembang dan Pengelola}

Konsep mixed useakantepat jika kompleks tersebut memiliki konsumen yang memang berada di sekitar bangunan. Braga City Walk dengan tema lifestyle center yang diusung, semakin membuat jarak antara fungsi bangunan dengan lingkungan sekitar.

Pada akhirnya strategi pengembangan Braga City Walk berujung pada strategi yang sifatnya survival. Ruang sewa yang tidak terjual disewakan untuk produk-produk di bawah kelas 
target konsumen. Keputusan melakukan pencampuran kelas tersebut justru membuat Braga City Walk semakin sulit mempertahankan nilai fasilitasnya.

\section{c. Segmentasi dan Perilaku Konsumen}

Konsumen yang sudah mengutamakanlifestyle, leisure, dan entertainment merupakan kalangan menengah ke atas, bahkan bisa jadi lebih terfokus pada kalangan atas karena termasuk dalam kebutuhan tersier. Konsumen pada tingkat ini, akan mengunjungi sebuah pusat perbelanjaan dengan tujuan rekreasi. Karakter ini menuntut jumlah varian produk yang dapat dipilih, yang pada akhirnya menuntut luasan area perbelanjaan yang luas yang tidak dimiliki oleh Braga City Walk.

\section{d. Karakter Produk}

Karakter produk pada sebuah pusat perbelanjaan erat kaitannya dengan karakter dan perilaku target konsumen. Sebuah lifestyle center seharusnya didukung oleh produk-produk yang memiliki nilai prestisius. Pada perencanaan awal Braga City Walk, tidak tampak adanya anchor tenant yang memiliki kriteria produk yang sesuai dengan target konsumen.

\section{e. Konsep Ekonomi Wilayah}

Dengan kondisi kegiatan ekonomi lingkungan yang lesu, membuat kawasan ini memiliki faktor ekonomi eksternal yang negatif.Dengan kondisi tersebut, Braga City Walk harus cukup mampu berdiri sendiri. Dengan areal kompleks yang luas, sebuah mixed use dapat menyediakan berbagai varian kegiatan dan produk yang dibutuhkan oleh lifestyle center. Namun, tuntutan ini tidak seiring dengan kondisi tapak Braga City Walk yang terbatas.

\section{Faktor Fisik}

\section{a. Lokasi dan Lingkungan Sekitar (Eksternal)}

Lokasi kompleks ini berada di area konservasi di Jalan Braga, Bandung.Fungsi lingkungan sekitar kebanyakan berupa restoran, minimarket, hotel, tempat hiburan, toko-toko. Di sisi kanan kiri Jalan Braga kompleks pertokoan memiliki arsitektur dan tata kota yang tetap mempertahankan ciri arsitektur lama pada masa Hindia Belanda. Namun, area tapak yang terbatas serta Jalan Braga yang relatif pendek kurang mendukung dibangunnya lifestyle center dengan konsep leisure and entertainment yang menuntut banyak varian aktivitas. 


\section{b. Bentuk, Tata Ruang dan Sirkulasi (Internal)}

Bentuk kompleks mengadopsi konsep pedestrian mall melanjutkan pertokoan di sepanjang Jalan Braga.Tata ruang toko-toko dibuat berjajar mengikuti pola linear jalur sirkulasi. Pada lahan yang terbatas tersebut alur linear pada akhirnya membentuk pola circuit, yaitu pola sirkulasi yang akan membawa pengunjung kembali ke titik awal dimulainya perjalanan. Namun, pada desain bangunan ini pada lantai 1 dan 2 justru terjadi sirkulasi yang buntu, kondisi ini sebenarnya dapat diupayakan dengan menetapkan penyewa yang memiliki daya tarik pengunjung yang cukup besar (anchor tenant). Namun, ternyata ruang sewa yang ditempati bukan oleh anchor tenant atau bahkan kosong.

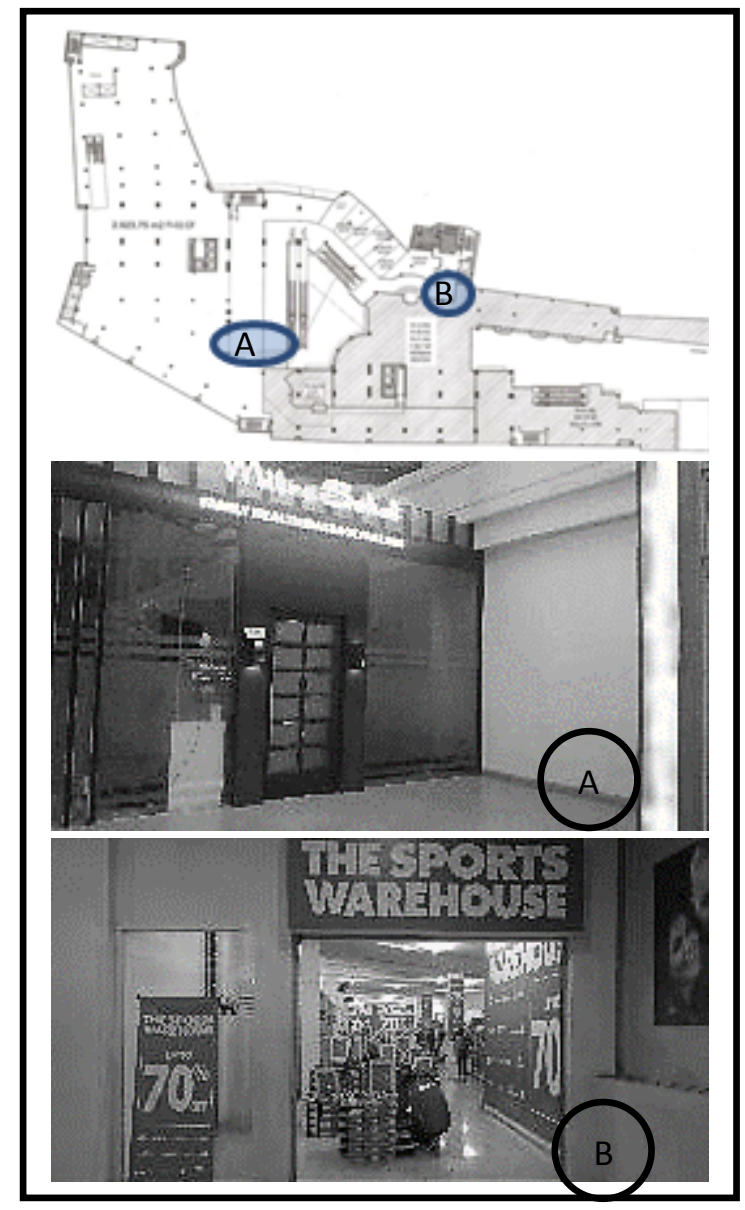

Gambar 12. Sirkulasi buntu pada Lantai 1 Sumber: Dokumentasi pribadi, 2015 


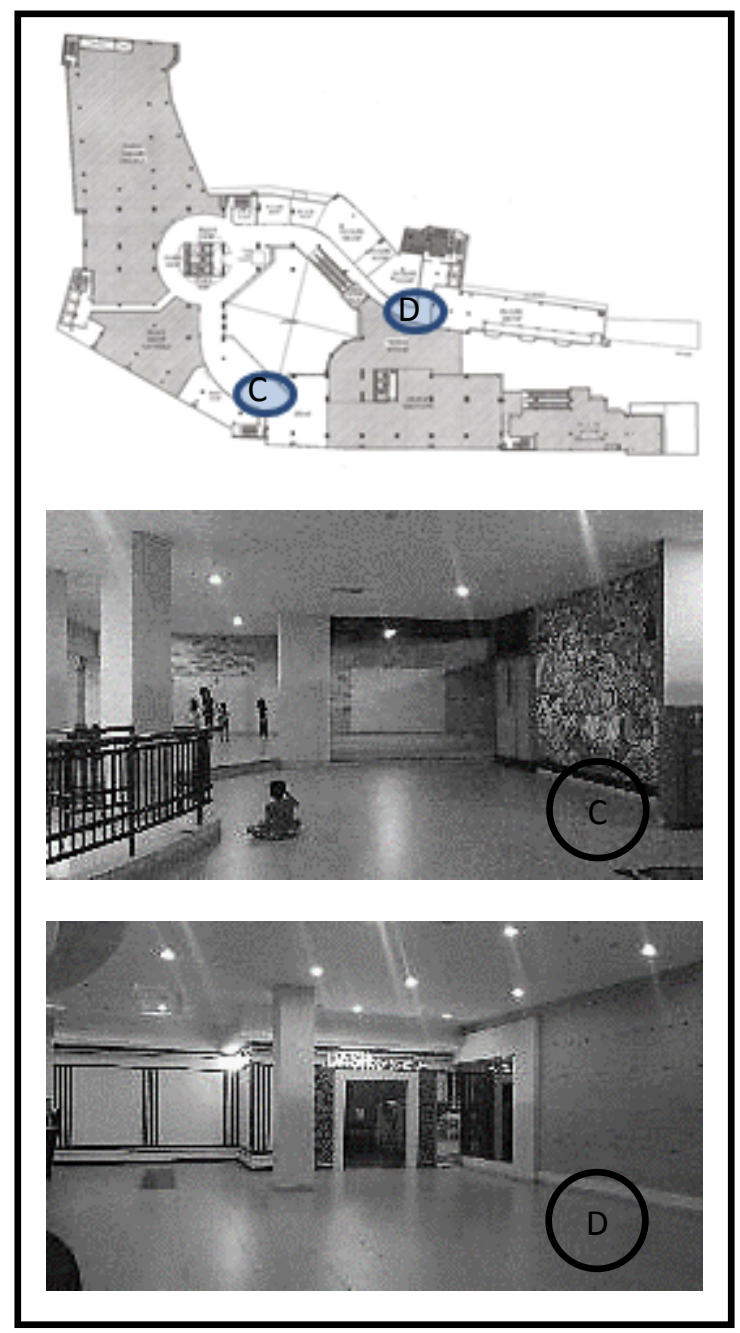

Gambar 13. Sirkulasi buntu pada Lantai 2 Sumber: Dokumentasi pribadi, 2015

\section{c. Material dan Detail (Internal)}

Material yang digunakan pada bangunan ini bukanlah material yang sesuai dengan kelas sebuah lifestyle center. Detil penyelesaiannya pun tidak digarap dengan baik. Hal ini turut mempengaruhi citra bangunan sehingga target pengguna yang diharapkan pun meleset.

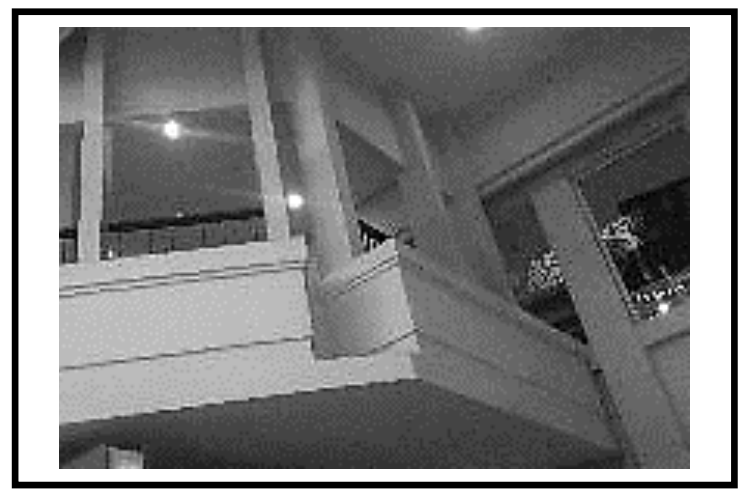

Gambar 14. Detail penyelesaian yang kurang baik Sumber: Dokumentasi pribadi, 2015 


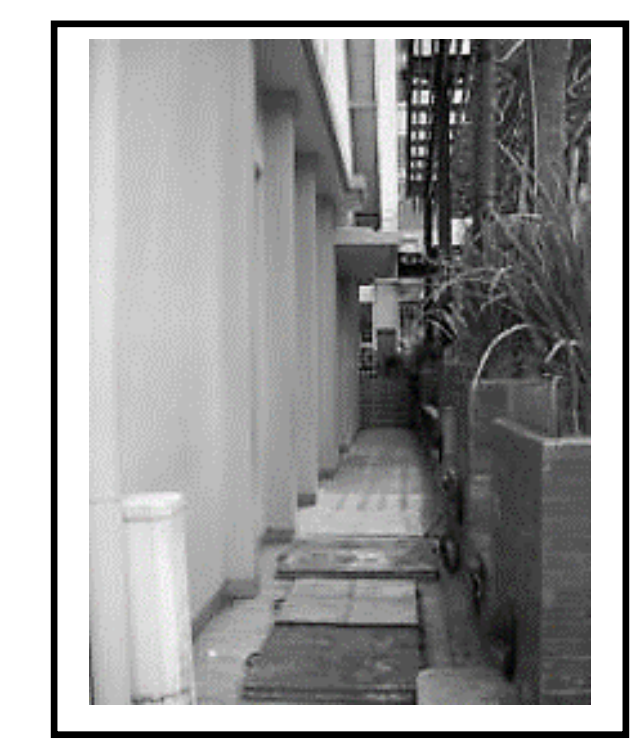

Gambar 15. Pemilihan material dan detil kurang baik Sumber: Dokumentasi pribadi, 2015

\section{d.Analisis Perubahan Fisik}

Urutan pembahasan dibuat berdasarkan pada Tabel 5.

(A) Pemilihan fungsi ruang pertemuan dengan prosentase pemakaian ruang yang besar terbukti tidak efektif. Konsep awal yang ingin menjadikan Braga City Walk sebagai meeting point dirasakan kurang tepat karena lokasi bangunan yang dikelilingi oleh fungsi hotel dan perkantoran yang pada umumnya justru sudah memiliki meeting room. Sedangkan Hotel Aston yang merupakan salah satu fungsi dalam mixeduse kompleks ini pun sudah memiliki meeting room sendiri.

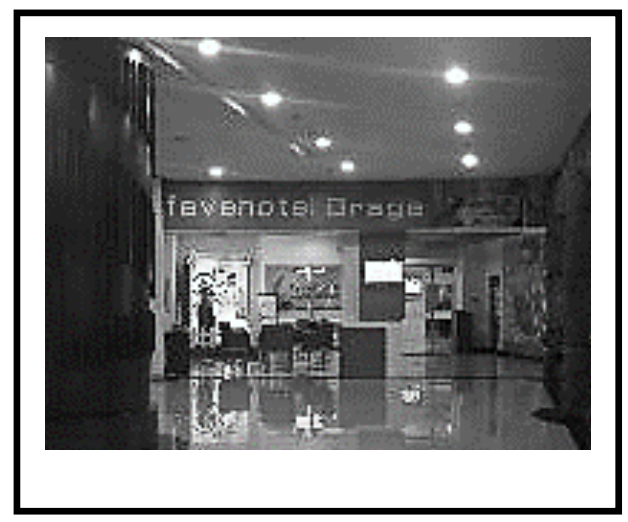

Gambar 16. Lobby Fave Hotel

Lantai satu - Braga City Walk Sumber: Dokumentasi pribadi, 2015

(B) Eskalator ini pada dasarnya sudah kurang efektif karena terdiri dari 1 (satu) unit saja, arah naik atau turun. Keputusan menghilangkan eskalator ini dilatarbelakangi kebutuhan fasilitas 
travelator (pada perubahan fungsi sebelumnya) untuk sebuah pusat perbelanjaan yang menyediakan sebuah hypermarket. Namun, hal tersebut sangat disayangkan tidak diikuti oleh pembenahan sirkulasi vertikal yang seharusnya tetap menghubungkan antar lantai tanpa terputus atau pun harus kembali memutar ke titik awal.

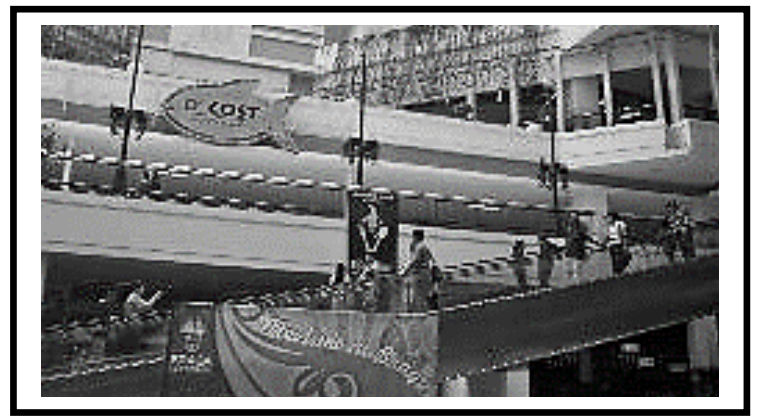

Gambar 17. Travelator di area void saat masih ada hypermarket Sumber: Dokumentasi pribadi, 2008

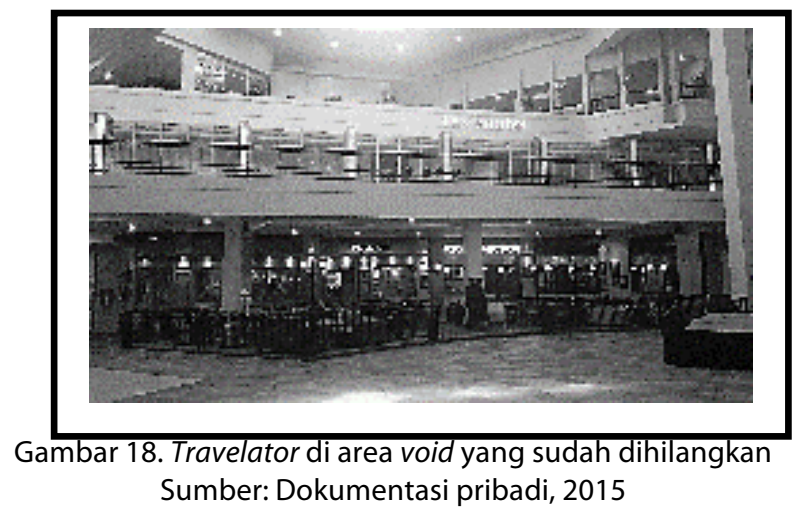

(B) Setelah penempatan fungsi hypermarket pun harus diganti, area tersebut saat ini dipergunakan sebagai hotel yang memiliki manajemen yang sama dengan hotel yang sudah lebih dahulu ada.

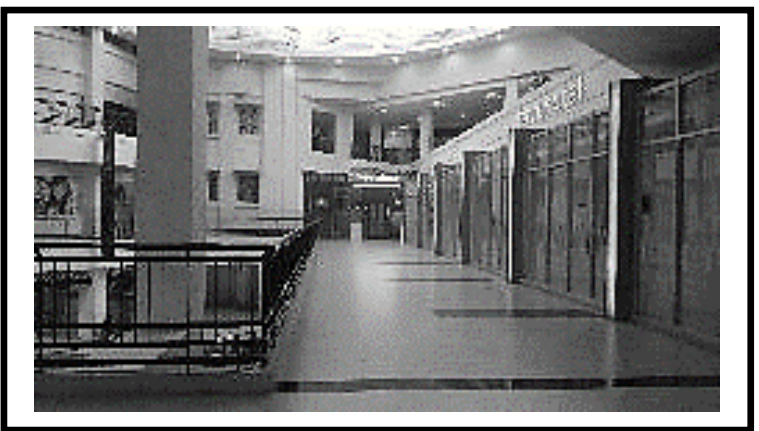

Gambar 19. Ballroom dan meeting room Fave Hotel Lantai dua - Braga City Walk Sumber: Dokumentasi pribadi, 2015

(D) Sebuah fungsi wellness center harus memiliki akses yang terpisah dari kegiatan perbelanjaan. Dengan pertimbangan jam kerja yang berbeda dengan fungsi tempat 
perbelanjaan. Jadi relokasi fungsi wellness center ke bagian depan kompleks sudah merupakan keputusan yang tepat.

"The health club should be suitably located to provide convenient visitor access and separate servicing access. It is preferable if the entrance can be positioned so as to be independent of the shopping facilities, to allow for out of trading hours access."

(Coleman, 2006:320)

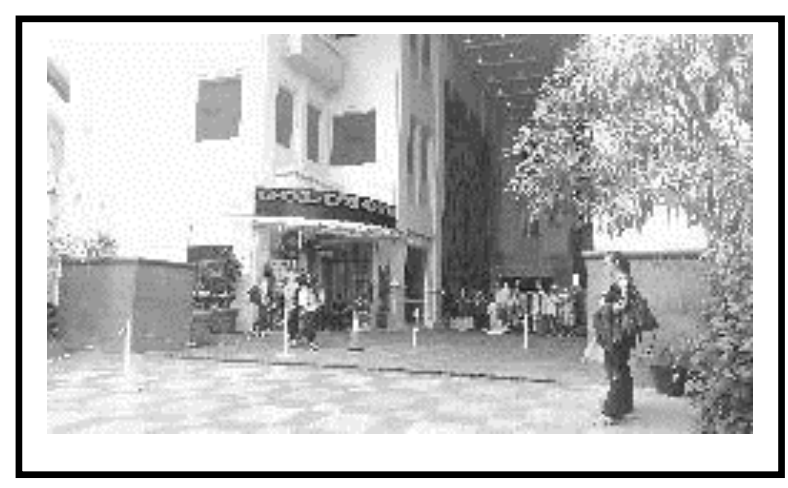

Gambar 20. Gold Gym Braga City Walk

Sumber: Dokumentasi pribadi, 2015

(E) Perubahan void tidak terlalu berpengaruh pada aktivitas yang terjadi karena hanya memberikan ambiance yang berbeda melalui tema desain. Pada tahun 2008 mengangkat tema tropis sedangkan tahun 2015 ini dengan tema modern-artdeco. Pengambilan tema artdeco dapat diapresiasi karena berusaha untuk konsisten dengan lingkungan bangunan ini berada yaitu daerah konservasi.

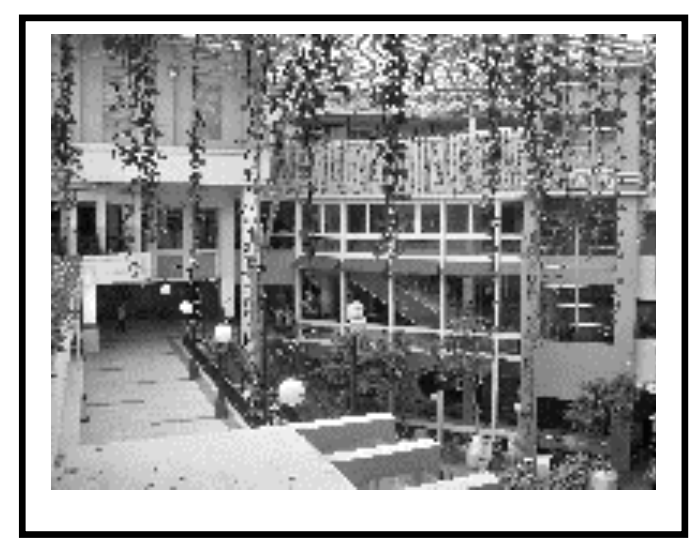

Gambar 21. Void Braga City Walk dulu Sumber: Dokumentasi pribadi, 2008 


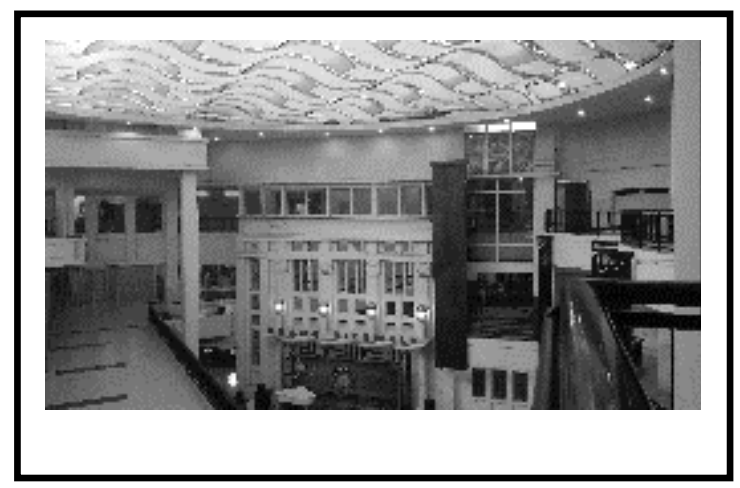

Gambar 22. Void Braga City Walk sekarang Sumber: Dokumentasi pribadi, 2015

(F) Ruang yang terbentuk akibat desain bangunan pada area ini berbentuk koridor dengan deretan ruang sewa yang ukurannya $r$ slatif kecil. Bentukan ruang seperti ini membuat pengunjung enggan untuk melewati ko idor tersebut. Perubahan peruntukan ruang sewa ini juga dinilai tepat. INamun di sisi lair penempatan ruang sewa berukuran besar justru kembali membuat jalun buntu baru 'neski diupayakan membuat cascade kecil untuk sirkulasi.

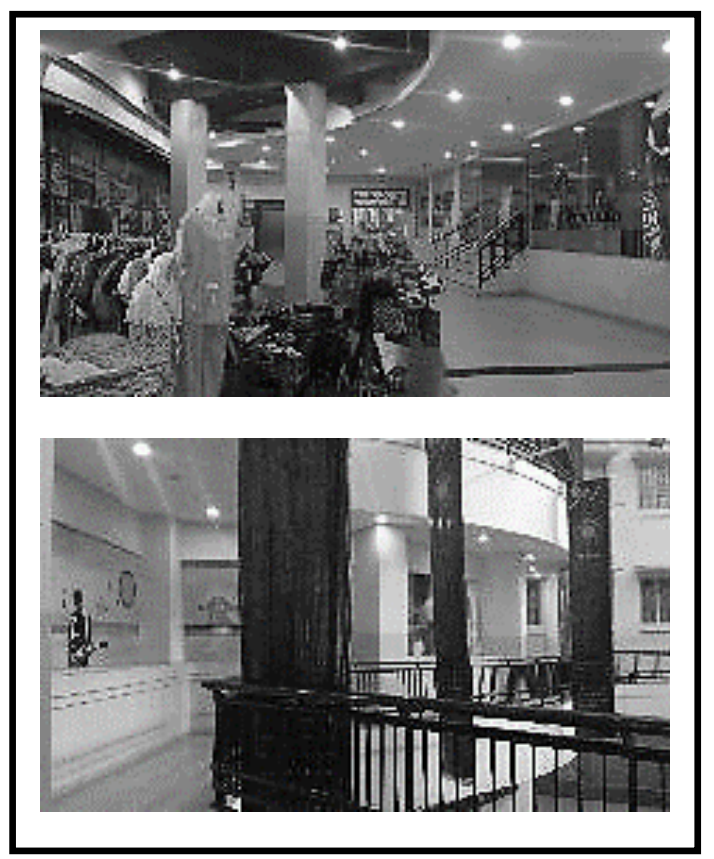

Gambar 23. Ruang sewa karaoke di lantai satu (atas) Arcade untuk sirkulasi yang tidak memiliki daya tarik (bawah)

Sumber: Dokumentasi pribadi, 2015 
(G) Food court direncanakan sebagai daya tarik ke arah vertikal bangunan. Namun dengan lesunya area retail di bangunan ini, membuat sebuah food court pun tidak cukup memiliki daya tarik.Food court tersebut terletak di lantai paling atas kompleks retail, tidak memiliki dukungan daya tarik yang membuat pengunjung mau berupaya mencapai tempat tersebut. Perubahan fungsi food court menjadi ruang sewa berukuran besar (kegiatan keagamaan) seperti halnya dilakukan di lantai satu dengan memunculkan masalah yang sama.

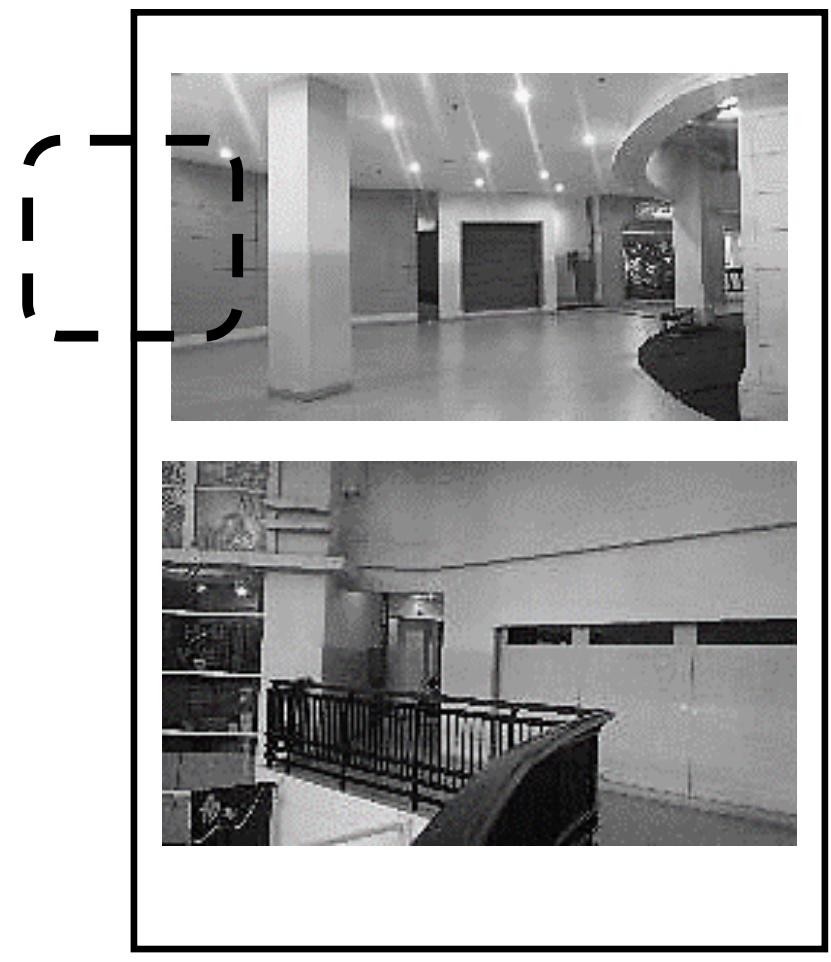

Gambar 24. Pintu menuju ruang sewa keagamaan di lantai dua (atas) Arcade untuk sirkulasi yang tidak memiliki daya tarik (bawah) Sumber: Dokumentasi pribadi, 2015

\section{PENUTUP}

Perencanaan sebuah fungsi dan konsep bangunan erat kaitannya dengan analisis kondisi tapak, lingkungan sekitar tapak, sosial budaya masyarakat sekitar tapak, strategi pengembangan fungsi, dan faktor fisik yang langsung berhubungan dengan pengguna yakni aspek tata ruang dan sirkulasi.Evaluasi pasca huni dapat menemukan indikasi masalah dengan lebih cermat.

Braga City Walk digagas juga untuk dapat memperpanjang jalur pedestrian Jalan Braga dengan 'menarik' alur pejalan kaki ke dalam area Braga City Walk. Perpanjangan jalur sirkulasi pedestrian tersebut berusaha mengangkat kondisi Jalan Braga yang saat itu memang belum bergairah.Mengacu pada definisi lifestyle center, baik Jalan Braga maupun 
Braga City Walk tidak memiliki cukup varian pilihan bagi pengunjung. Dengan kata lain keterbatasan lahan menjadi salah satu faktor kendala.

Keterbatasan lahan perlu disiasati dengan seksama melalui pemilihan jenis pola sirkulasi dalam perancangannya. Pola sirkulasi seyogyanya diarahkan untuk memiliki sirkulasi yangmenerussehingga pengunjung akan seolah terbawa alur mengitari semua ruang sewa supaya dapat terlihat dengan baik.

Terkait tuntutan varian yang banyak untuk sebuah lifestyle center maka pada kasus Braga City Walk, faktor yang mempengaruhi nilai bangunan ini juga adalah penentuan fungsi, dalam hal ini pertimbangan karakter ruang sewa, yang kemudian mempengaruhi desain tata ruang dan serta merta membentuk pola sirkulasi di dalam bangunan. Bentuk dan tata ruang sewa sangat dipengaruhi oleh siapa bakal calon penyewa ruang tersebut, jenis produk dan luasan yang dibutuhkan. Oleh karena itu, perlu kembali mengingat definisi dan karakter sebuah lifestyle center.

Karena dinilai berakar pada masalah pertimbangan karakter ruang sewa, maka solusi yang disarankan adalah dengan membuat konsep baru dengan melihat pada potensi lingkungan sekitar. Dengan latar belakang diminatinya kawasan Braga sebagai obyek wisata, besar kemungkinan jika konsep fungsi Braga City Walk dialihkan menjadi konsep wisata maka akan memberikan perubahan yang diharapkan. Apalagi mengingat potensi kompleks yang sudah memiliki fungsi hotel, serta bangunan Braga City Walk yang sudah memiliki fasilitas areal parkir di basement.

Keterbatasan lahan untuk sebuah lifestyle center yang dituntut dapat menjawab kebutuhan, cukup sulit untuk diubah. Namun, jika diperhatikan di pemukiman di sekitar Jalan Braga sebenarnya terdapat kumpulan seniman lukis yang juga sering menjual hasil karyanya di ruas Jalan Braga.Hal tersebut mungkin justru dapat menjadi titik tolak penentuan konsep baru. Dengan adanya nama besar Jalan Braga di mata para wisatawan, maka dapat saja diusung dengan konsep wisata berupa sentralisasi kegiatan budaya dan seni lokal yang dapat menjadi daya tarik.

Selanjutnya perbaikan fisik yang mutlak harus dilakukan adalah membentuk kembali pola sirkulasi circuit yang ideal, supaya pengunjung diarahkan secara nyaman untuk mengitari 
kompleks tanpa menemui ruang-ruang buntu tanpa daya tarik. Pembenahan pola sirkulasi tersebut juga akan mempengaruhi bentuk dan besaran ruang sewa.

\section{DAFTAR PUSTAKA}

Bromley, Rosemary D., Thomas, Colin J. (1993). Retail Change-contemporary Issues.UCL Press. Coleman, Peter. (2006). Shopping Environments-Evolution, Planningand Design. Oxford: Architectural Press.

Hardjasaputra, A. Sobana. (2007). Penataan Braga: "Sejarah Berulang". Dimuat dalam Harian Pikiran Rakyat, Bandung 28 Maret 2007.

Kunto, Haryoto. (1984). Wajah Bandoeng Tempo Doeloe. Bandung: PT. Granesia.

Reikli, Melinda. (2012).The Key of Success in Shopping Centers.PhD Disertation Doctoral School of Bussiness Administration Corvinus University of Budapest.

Suwarni, Yuli Tri. (2004). Heat Put On Braga Street Development. Dimuat dalam Harian The Jakarta Post, Jakarta 13 April 2004. 